九州大学学術情報リポジトリ

Kyushu University Institutional Repository

\title{
LOSS OF TREE VIGOR AND ROLE OF BORING INSECTS IN RED PINE STANDS HEAVILY INFESTED BY THE PINE NEEDLE GALL MIDGE IN KOREA
}

Ko, Je-Ho

Entomological Laboratory, Faculty of Agriculture, Kyushu University

Morimoto, Katsura

Entomological Laboratory, Faculty of Agriculture, Kyushu University

https://doi.org/10.5109/2482

出版情報: ESAKIA. 23，pp.151-158，1985-11-30. Entomological Laboratory，Faculty of Agriculture, Kyushu University

バージョン：

権利関係 : 


\title{
LOSS OF TREE VIGOR AND ROLE OF BORING INSECTS IN RED PINE STANDS HEAVILY INFESTED BY THE PINE NEEDLE GALL MIDGE IN KOREA ${ }^{12) 31}$
}

\author{
JE-HO Ko \\ Department of Forest Entomology and Pathology, \\ Forest Research Institute, Seoul 131, Korea \\ and \\ KATSURA MORIMOTO \\ Entomological Laboratory, Faculty of Agriculture, \\ Kyushu University, Fukuoka, Japan
}

\begin{abstract}
Ten species of tree borers in 3 families were collected from bait logs and dead trees in red pine forests infested by the pine needle gall midge, Thecodiplosis japonensis. They are secondary pests and played a minor role in causing tree mortality in the stands studied. Red pine stands with about $14 \mathrm{k} \Omega$ of cambial electrical resistance on an average in May were very vital ; those with over $21 \mathrm{k} \Omega$ were in high mortality as a result of attacks by the pine gall midge.
\end{abstract}

\section{Introduction}

Observations on the red pine, Pinus densiflora, attacked by the pine gall midge show that needle damage reaches $50-80 \%$ after 5-7 years since initial infestation. When the damage is very severe, tree mortality reaches about $30 \%$ in a year. Parasitization by platygastrid wasps ensues after the midge has invaded new territory, and the percentage parasitism increases most sharply after the midge density has peaked. When the percentage parasitism rises above $15 \%$, the percentage of damaged needles decreases to about $10 \%$, and the populations of the midge and the wasps reach an equilibrium.

1) Partly supported by a grant (1983-84) from the Japan Society for the Promotion of Science, Tokyo (Principal investigators : T. Miura and J. H. Ko).

2) Contribution from the Department of Forest Entomology and Pathology, Forest Research Institute, Seoul, Korea.

3) Contribution from the Entomological Laboratory, Faculty of Agriculture, Kyushu University, Fukuoka (Ser. 3, No. 195). 
Vigor of red pines weakened by the midge attack and that of healthy red pines were compared by measuring the electrical resistance with the Shigometer and by observing the amount of resin flow from punch-hole. Concurrently a survey was made of species of boring beetles in trees damaged by the midge.

This was the first experiment conducted in Korea with the Shigometer. We are very much indebted to Prof. Y. Hirashima of Japan and Dr. A. L. Shigo of the USA for their comments in the course of planning and executing this work with the Shigometer.

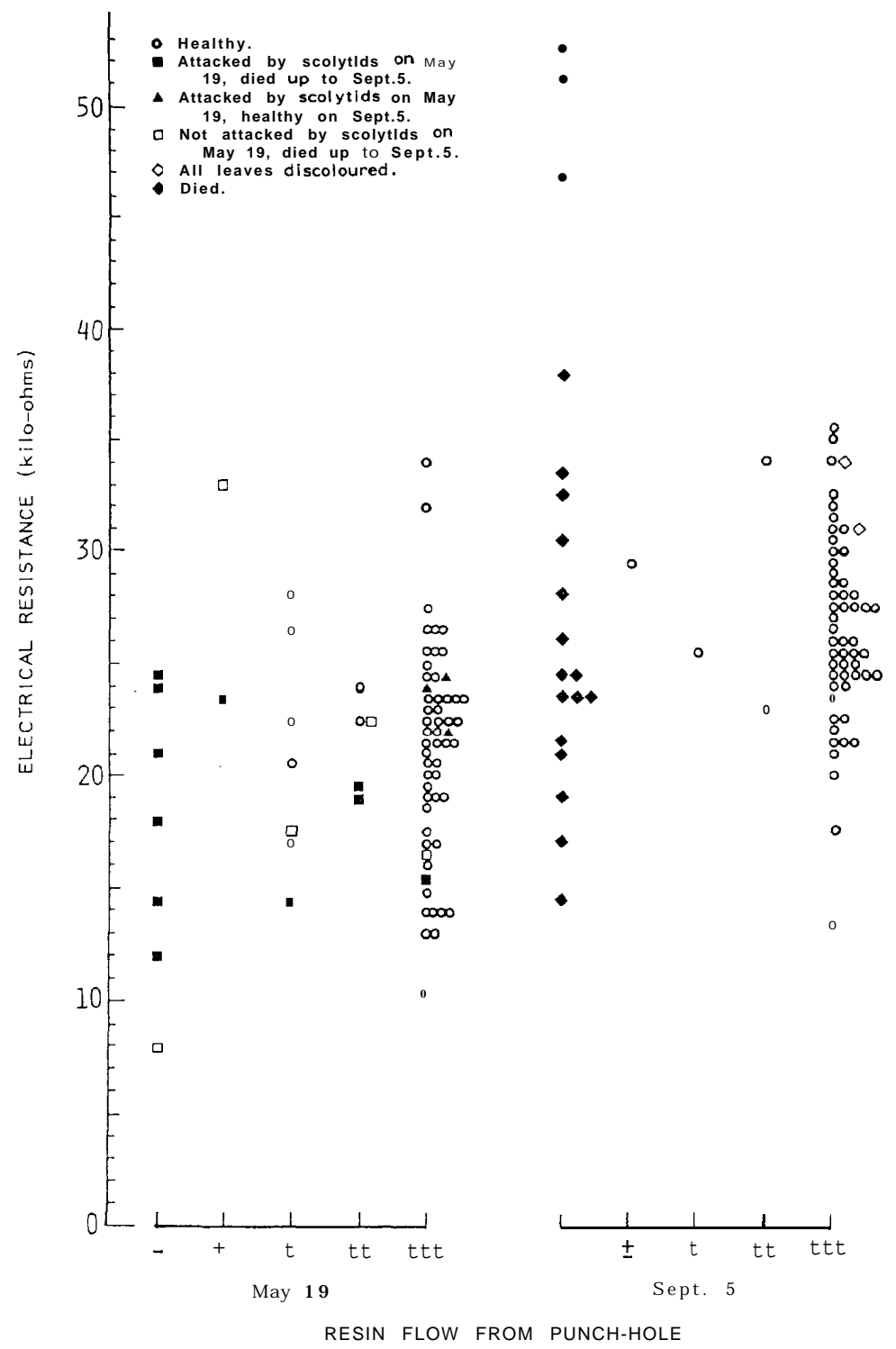

Fig. 1. Relationship between resin flow and phloem electrical resistance of red pine. 


\section{Materials and Methods}

Locations and conditions of the pine stands studied in Gang-won-do and Seoul are listed in Table 1.

Stands A and B in Duch'ǒn-myon are proximate in location and their midgeinfestation histories were presumably similar. The parasitic wasp, Inostemma seoulis, was liberated there in 1980. The stand in Nam-myon was lightly infested by the gall

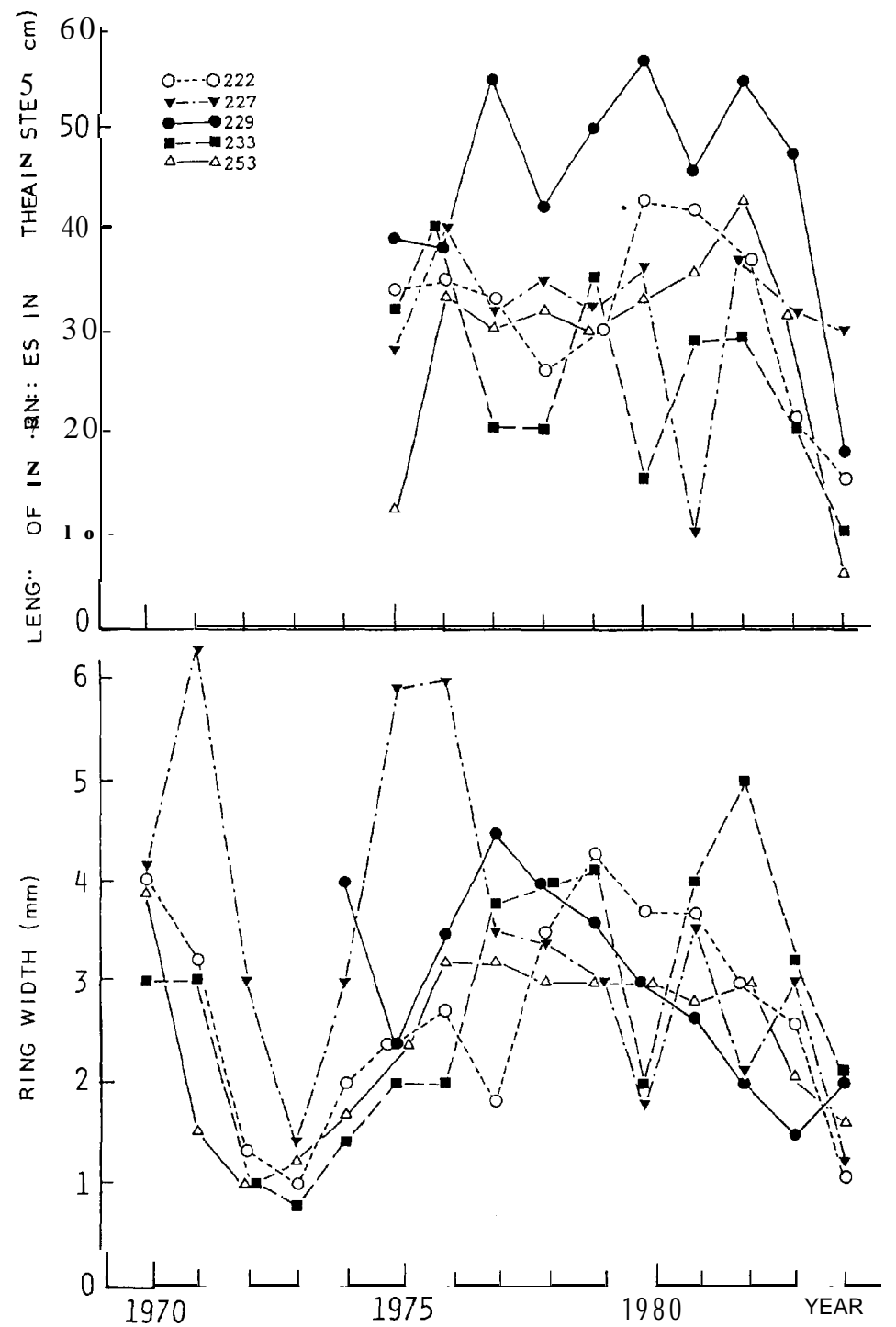

Fig. 2. Annual height and diameter growth of the red pine infested by the pine gall midge. 
Table 1. Locations and conditions of the pine stands studied.

\begin{tabular}{llcccccc}
\hline $\begin{array}{l}\text { Stand } \\
\text { locations }\end{array}$ & $\begin{array}{l}\text { Age } \\
\text { (years) }\end{array}$ & DBH(cm) & Onset of & \multicolumn{4}{c}{ Infested needles $(\%)$} \\
infestation & 1980 & 1981 & 1982 & 1983 \\
\hline Duchon-myon A $^{\text {a) }}$ & $15-34$ & $17.7 \pm 5.1$ & 1975 & 20.9 & 56.1 & 64.6 & 45.2 \\
Duchon- myon B B) $^{\text {a) }}$ & $10-40$ & $14.9 \mathrm{f} 7.3$ & 1975 & & & & \\
Nam- myon $^{\text {b) }}$ & $20-25$ & $15.7 \pm 3.1$ & 1978 & - & 19.6 & 15.2 & $20.2)^{\prime}$ \\
Seoul d) & $60-70$ & $16.8 \pm 4.1$ & 1950 & - & 41.2 & 22.0 & 4.2 \\
\hline
\end{tabular}

a) Jaeun-ri, Duch'ǒn-myon, Hongcheon-gun.

b) Shinnam-ri, Nam-myon, Inje-gun.

c) Data from an adjacent stand.

d) Chongyangni, Experimental Forest.

midge in 1984, and the trend of the infestation measured at an adjacent stand, where the wasp was liberated in 1981, is provided in Table 1. The stand in Seoul is at the experimental forest of the Forest Research Institute, where Inostemma seoulis was first found in 1962 .

The relative vitality of red pines was estimated by measuring cambial electrical resistance with the Shigometer R model 7950 (Wargo and Skutt, 1975 ; Shortle et al., 1977 ; Blanchard and Carter, 1980 ; Davis et al., 1980), and by the punch-hole method (Oda, 1967). For measuring the electrical resistance, two readings were taken from opposite sides of the stem at $1.4 \mathrm{~m}$ above ground and another two readings at the base for every tree. The pins of Shigometer were aligned vertically and inserted perpendicular to the bole of the tree. On thick-barked trees, the pins were driven into the bark with a wooden mallet. The relative vitality was also estimated by making circular punchholes $(10 \mathrm{~mm}$ in diameter) through the bark and into the cambial region and observing the amount of resin flow one day after punching. Tree resin flow was graded as follows :

- : Resin flow nil.

土: Inside of hole sticky to the touch.

+ : Resin gathered in the bottom of hole.

++ : Resin flowed less than $10 \mathrm{~cm}$ from hole orifice.

+++ : Resin flowed more than $10 \mathrm{~cm}$ from hole orifice.

Tree-boring beetles were collected from bait logs set in Chunch'øn City, Honch'ŏn-gun, Inje-gun, and Yang-yang-gun, and also from felled trees and trunks of dead standing trees. Eight trees in the Duch'on-myon A stand were felled on Sept. 6, and the annual height growth, diameter growth and attacking beetles were examined.

\section{Results}

The following is a listing of the tree-boring beetles collected from the bait logs and dead trees : 
Family Cerambycidae

Asemum amurense Kraatz

Family Curculionidae

Pissodes nitidus Roelofs

Shirahoshizo rufescens (Roelofs)

Hylobitelus haroldi (Faust)

Niphades variegatus (Roelofs)

Family Scolytidae

Hylastes parallelus Chapuis

Hylastes plumbeus Blandford

Hylurgops interstitialis (Chapuis)

Tomicus piniperda (Linnaeus)

Cryphalus fulvus Niijima

The species listed are mostly active from April to May, and in May, scolytids cause pitch tubes to form on the trunks of weakened trees. Shigometer readings of cambial electrical resistance are summarized in Table 2.

Fig. 1 shows the relationship between the cambial electrical resistance and the tree grades as classified by the punch-hole method. All but one of the trees with the lowest resin flow on May 19 had been attacked by scolytids and died prior to Sept. 5 .

Table 2. Electrical resistance (mean $\pm \mathrm{SD}$, in kilo-ohms).

\begin{tabular}{|c|c|c|c|c|c|}
\hline Date & $\begin{array}{l}\text { Measured } \\
\text { point }\end{array}$ & $\begin{array}{c}\text { Duch'ǒn-myon } \\
\text { (A) }\end{array}$ & $\begin{array}{l}\text { Duch'ǒn-myon } \\
\text { (B) }\end{array}$ & Nam-myon & Seoul \\
\hline \multirow[t]{3}{*}{ May 19} & $1.4 \mathrm{~m}$ & $21.5 \pm 5.4$ & $19.2 \pm 2.2$ & $14.0 \pm 2.7$ & $14.4 \pm 3.5^{\mathrm{a})}$ \\
\hline & $\begin{array}{l}\text { Root } \\
\text { collar }\end{array}$ & $21.9 f 5.3$ & $22.7 \pm 4.1$ & $15.8 \mathrm{f} 2.6$ & $14.3 \mathrm{f} 3.8$ \\
\hline & $1.4 \mathrm{~m}$ & $27.3 \pm 8.0$ & $26.0 \pm 3.2$ & $26.4 \pm 2.3$ & $17.7 \pm 3.4^{\mathrm{b})}$ \\
\hline Sept. 5 & $\begin{array}{l}\text { Root } \\
\text { collar }\end{array}$ & $26.6 \pm 6.7$ & $25.5 \pm 3.9$ & $24.6 \pm 2.5$ & $16.4 \pm 3.8$ \\
\hline
\end{tabular}

a) May 22. b) Sept. 24.

Table 3. The data on the felled trees (Duch'orn-myon A).

\begin{tabular}{|c|c|c|c|c|c|c|c|c|}
\hline \multirow{2}{*}{ No. } & \multicolumn{2}{|c|}{ Resin grade } & \multirow{2}{*}{$\mathrm{DBH}(\mathrm{cm})$} & \multirow{2}{*}{$\begin{array}{l}\text { Height } \\
\text { (m) }\end{array}$} & \multirow{2}{*}{$\begin{aligned} \text { Height to main } \\
\text { branch }(\mathrm{m})\end{aligned}$} & \multirow{2}{*}{$\mathrm{C}_{\text {ones }}$} & \multirow{2}{*}{ Needles } & \multirow{2}{*}{ Beetles* } \\
\hline & May 19 & Sept. 5 & & & & & & \\
\hline 222 & +++ & +++ & 22.9 & 12.0 & 8.0 & many & green & nil \\
\hline 223 & +++ & \pm & 20.7 & 9.1 & 4.6 & few & green & \\
\hline 227 & +++ & - & 22.9 & 12.1 & 6.7 & many & dead & $\mathrm{P}, \mathrm{S}, \mathrm{SC}$, Cer. \\
\hline 229 & +++ & +++ & 9.2 & 8.1 & 3.4 & many & green & \\
\hline 233 & +++ & + & 20.7 & 11.8 & 8.0 & many & mostly faded & \\
\hline 252 & +++ & ++ & 18.2 & 12.0 & 6.3 & many & partly faded & trace of $\mathrm{P}$. \\
\hline 253 & $++t$ & +++ & 19.1 & 11.5 & 5.5 & many & partly faded & trace of $\mathrm{P}$. \\
\hline 259 & ++ & - & 20.4 & 11.7 & 7.3 & many & dead & $\mathrm{P}, \mathrm{S}$, Fungi \\
\hline
\end{tabular}

* P:Pissodes nitidus. $S$ : Shirahoshizo rufescens. $\quad S C$ : Scolytids of Hylastes spp., Hylurgops interstitialis and Tomicus piniperda. Cer: Larvae of unidentified Cerambycidae.

Fung i : Cryptoporus volvatus. 


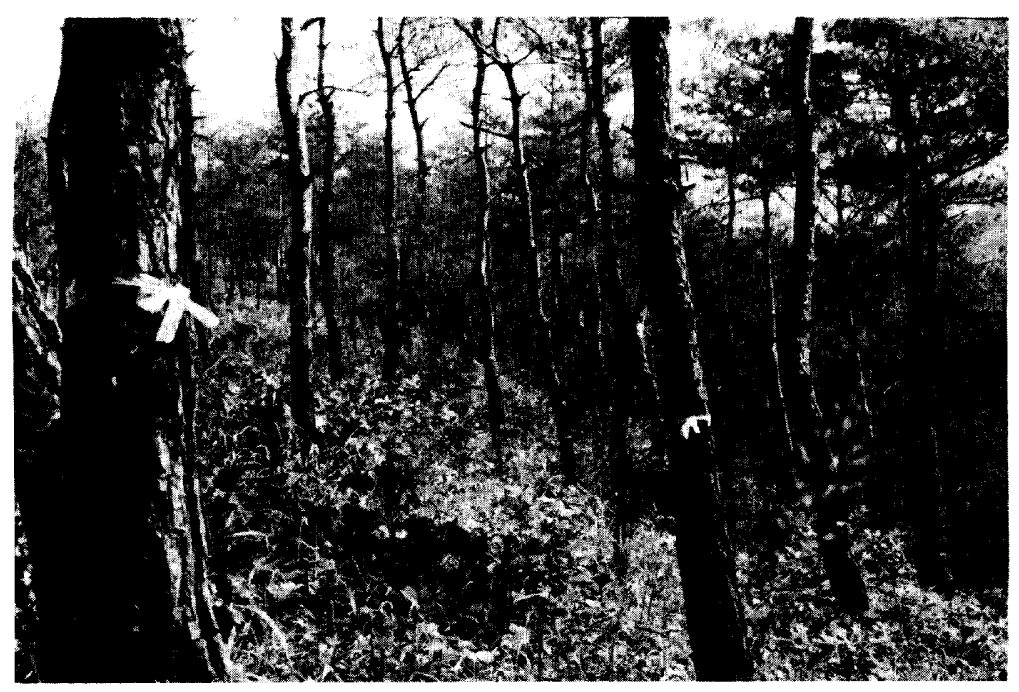

Fig. 3. Red pine trees infested by the pine gall midge at Jaeun-ri, Hongch'on-gun.

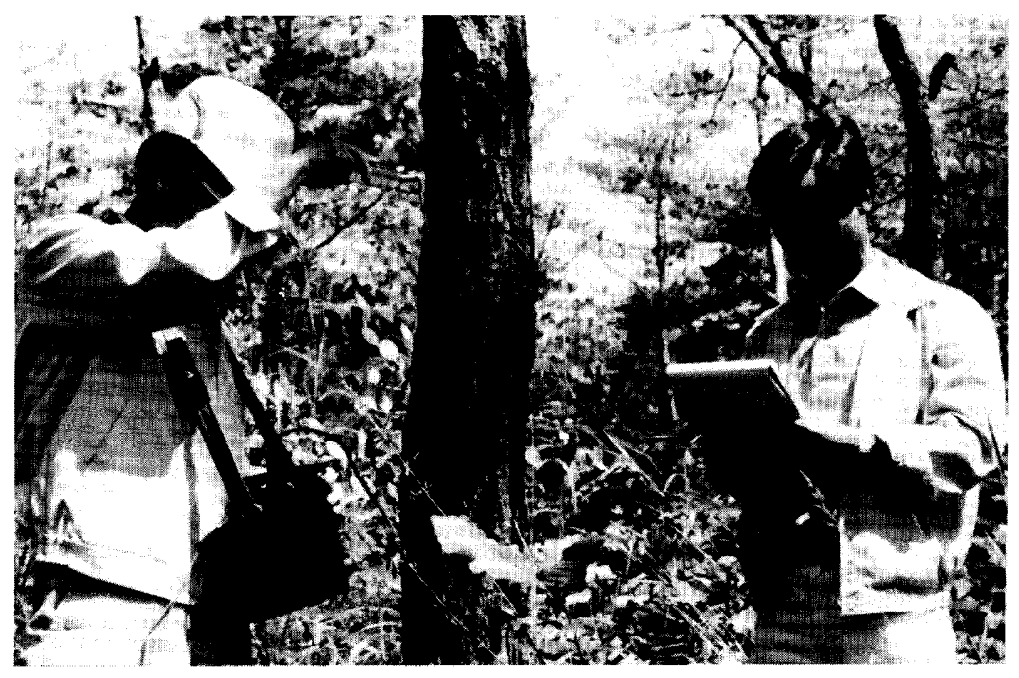

Fig. 4. Measuring the electrical resistance of a red pine with Shigometer.

On May 19, the electrical resistance was significantly lower in the Nam-myon and Seoul stands than in those at Duch'ôn-myon, but on Sept. 5, only that of the stand in Seoul was low. This method of comparing the vigor of stands is perhaps effective only in the growing season. The stands with an electrical resistance of about $14 \mathrm{k} \Omega$ on an average in May were vital, and those with over $21 \mathrm{k} \Omega$ were in high mortality.

The data on the felled trees at the Duch'on-myon A stand are shown in Table 3, and their annual growth increments are shown in Fig. 2. In about 1970 or 1971 and two or three years thereafter, diameter growth in this stand decreased, possibly indicating 


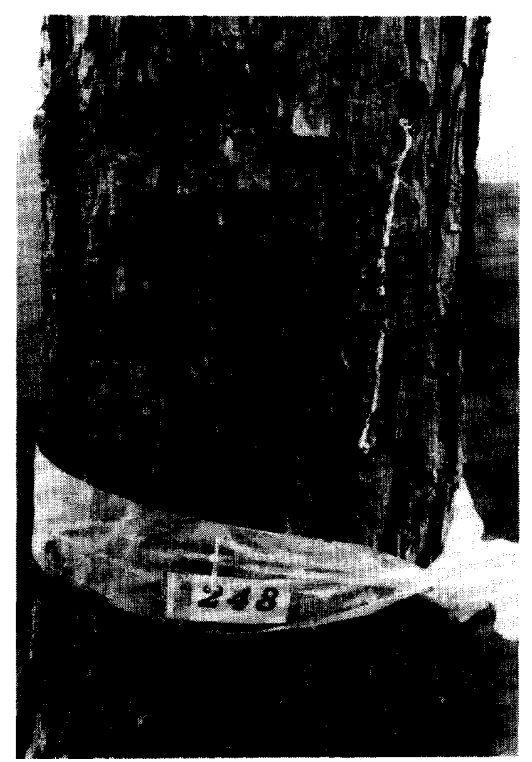

Fig. 5. Resin flow from the punch hole.

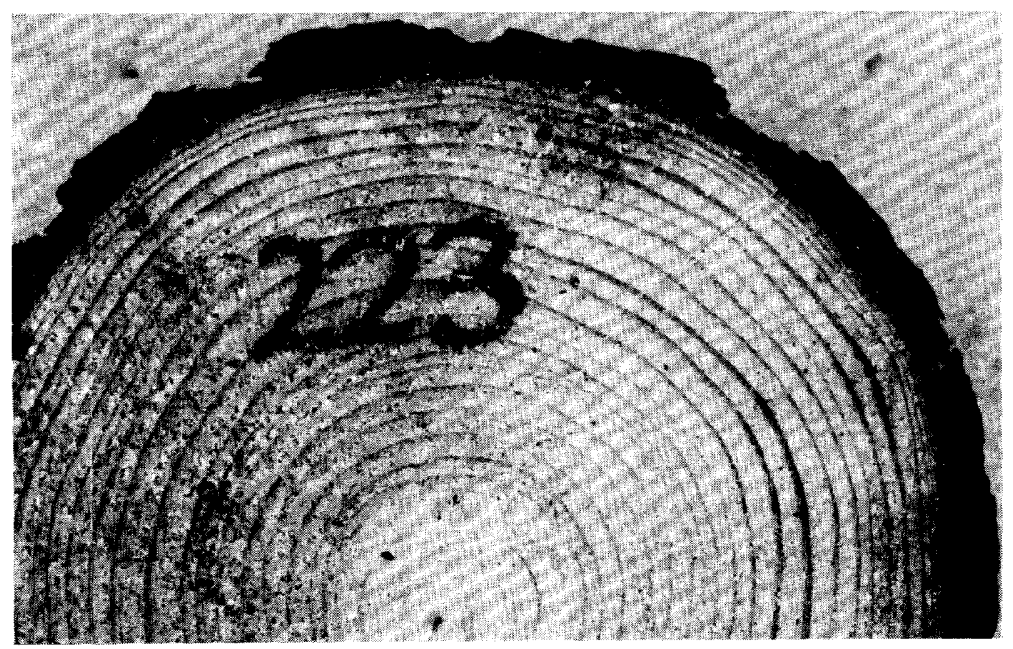

Fig. 6. Annual ring growth of the red pine infested by the pine gall midge.

attack by Dendrolimus spectabilis. Diameter growth recovered after 1973, but decreased again from 1976 through 1984. Height growth has markedly decreased since 1982. Their living top shoots were more or less limp and wilted. On Sept. 5, three of the felled trees with partly or mostly discolored needles showed normal resin flow from punch-holes, but two of them had been attacked by Pissodes, and many traces of larval feeding were observed under the bark. 


\section{Discussion}

In the heavily infested stands, red pine stands with abnormally low resin flow on May 19 had markedly decreased annual increments and many of their top shoots had died prior to Sept. 5. The relationship between the resin flow from punch-holes and the electrical resistance in cambial region was not detected in this experiment. However, compared with the electrical resistance of 13-18 $\mathrm{k} \Omega$ in spruce or fir trees infested by the spruce budworm in the USA (Davis, et al., 1980), that in red pines infested by the midge in Korea was about $6 \mathrm{k} \Omega$ higher.

Scolytids and weevils had usually attacked those weakened trees. The main cause of the low tree vigor in the stands studied was apparently the pine gall midge. Heavy infestation by this midge causes an immediate foliar reduction and an accompanying decline in height growth ; diameter growth decreases after one or two years of heavy foliar reduction. Wilt and die-back that have been induced by continuous heavy midge infestation are probably accelerated by low soil moisture. Trees heavily infested by the midge tend to produce heavy crops of cones.

The scolytids of the genera Hylastes and Hylurgops prefer weak or dying hosts and make evidence of attack consisting of pitch tubes with boring dust on the trunk. The weevils of the genera Pissodes and Shirahoshizo also attack weak or dying hosts ; because they lay eggs through small oviposition holes, evidence of their attack is observable only by peeling the bark. In three of the pine stands studied, scolytids attacked trees which had reduced resin flow on May 19. Most of these trees died prior to Sept. 5. By felling trees and scrutinizing the beetle galleries in them, it was determined that in most healthy trees with normal resin flow, oviposition does not occur or the developing beetle larvae die in early stadia. All trees with resin flow grades - and \pm on May 19 had died by Sept. 5, but mortality was very low among those with the grade +++ . These facts suggest that boring beetles attacked pine trees weakened or dying as a result of continuous damage by the pine needle gall midge and played a minor role in causing tree mortality in the stands studied.

\section{References}

Blanchard, R. 0. and J. K. Carter, 1980. Electrical resistance measurements to detect dutch elm disease prior to symptom expression. Can. J. For. Res., 10:111-113.

Davis, W., W. Shortle and A. Shigo, 1980. Potential hazard rating system for fir stands infested with budworm using cambial electrical resistance. Can. J. For. Res., 10 : 541-544.

Oda, K., 1967. On the trees susceptible to beetle attacks and their detection. Shinrin Boeki, 16: 263-266. (in Japanese)

Shortle, W. C., A. Shigo, P. Berry and J. Abusamra, 1977. Electrical resistance in tree cambium zone : Relationship to rates of growth and wound closure. Forest Sci., 23 : 326-329.

Wargo, P. M. and H. R. Skutt., 1975. Resistance to a pulsed current ; An indicator of stress in forest trees. Can. J. For. Res., 5: 557-561. 